\title{
Haemoglobin D Punjab (D Los Angeles)
}

\author{
F. VELLA* and H. LEHMANN†
}

\begin{abstract}
Summary. A search for haemoglobin variants undertaken in Canada revealed 21 unrelated instances of $\mathrm{Hb}$ D Punjab amongst 207,300 specimens tested. Of these, eight came from East Indian immigrants and the rest from Canadians of United Kingdom origin. No instances of $\mathrm{Hb} \mathrm{D}$ Punjab were found in 14,500 specimens from Canadian Indians that were tested. The geographical origins of 27 instances of $\mathrm{Hb}$ D Punjab characterized at the MRC Abnormal Haemoglobin Unit, Cambridge are presented. Of these five were natives of the British Isles. The results of surveys undertaken in the United Kingdom are summarized. The global distribution of $\mathrm{Hb} \mathrm{D}$ Punjab is discussed.
\end{abstract}

Haemoglobin D (Hb D) was the third abnormal haemoglobin to be reported (Itano, 1951; Sturgeon, Itano, and Bergren, 1955). It was discovered in a family of mixed British and American-Indian origin from the Los Angeles area, of which some members had a haemolytic anaemia with a tendency for the erythrocytes to sickle slowly on reduction. The characteristics of $\mathrm{Hb} \mathrm{D}$ were: (1) an electrophoretic mobility identical to that of $\mathrm{Hb} \mathrm{S}$ at alkaline $\mathrm{pH},(2)$ a normal solubility when in the reduced state, and (3) absence of sickling of erythrocytes which contain it in association with $\mathrm{Hb} \mathrm{A}$. The $\mathrm{Hb} \mathrm{D}$ in this family has been characterized as $\alpha_{2} \beta_{2}{ }^{121} \mathrm{Glu} \rightarrow \mathrm{Gln}$ and called D Los Angeles (Babin, Jones, and Schroeder, 1964).

Between the discovery of $\mathrm{Hb} \mathrm{D}$ and the elucidation of its molecular structure, abnormal haemoglobins with the same properties were found to occur in many ethnic groups. Thus, they were reported in white persons of European extraction (Dacie, 1954; White and Beaven, 1954; Chernoff, 1958) as well as in English (Stewart and MacIver, 1956; Smith and Conley, 1959), Portuguese (Arends, Layrisse, and Rincon, 1959), Italian (Bowman and Ingram, 1961), German (Martin et al, 1960), Greek (Gouttas et al, 1960), Turkish (Aksoy and Lehmann, 1956; Gammack et al, 1961), Persian (Hynes and Lehmann, 1956), Indian (Bird and Lehmann, 1956; Jacob, Lehmann, and Raper, 1956), as well as

Received 14 February 1974.

* Department of Biochemistry, University of Saskatchewan, Saskatoon, Sask, Canada. On sabbatical leave at $t$.

t MRC Abnormal Haemoglobin Unit, University Department of Biochemistry, Cambridge, United Kingdom.
American negro subjects (Chernoff, 1956; McCurdy, 1959; Marder and Conley, 1959). Five specimens of $\mathrm{Hb} \mathrm{D}$ of widely differing ethnic origin-namely Hb D Chicago (Bowman and Ingram, 1961); Hb D North Carolina (Smith and Conley, 1959); Hbs D Punjab, D Portugal, and D Cyprus supplied by Dr H. Lehmann-were all shown to have the composition $\alpha_{2} \beta_{2}{ }^{121 \mathrm{Glu} \rightarrow \mathrm{Gln}}$ (Baglioni, 1962). These findings demonstrated that this variant has a wide distribution. It was soon demonstrated that the electrophoretic and solubility properties of $\mathrm{Hb} \mathrm{D}$ were by no means specific for $\mathrm{Hb} \mathrm{D}$ Punjab by the discovery of many instances of $\mathrm{Hb} \mathrm{D}$ which have a different molecular structure from $\mathrm{Hb} \mathrm{D}$ Punjab. For example, D Baltimore (Marder and Conley, 1959), D Washington (McCurdy et al, 1961), D St Louis (Minnich et al, 1962), G Azuakoli (Lehmann and Nwokolo, 1959), G Bristol (Raper et al, 1960), G Philadelphia (Atawater, Schwartz, and Tocantins, 1960) all of which have the structure $\alpha_{2}{ }^{68 \text { Asn } \rightarrow \text { Lys }} \beta_{2}$ (Baglioni and Ingram, 1961; Weatherall, Sigler, and Baglioni, 1962; Dance, Huehns, and Shooter, 1964) as do also $\mathrm{G}_{\mathrm{St}-1}$ (Bowman et al, 1966) and $\mathrm{G}$ Knoxville (Chernoff and Pettit, 1965); while G Galveston is $\beta^{43 \mathrm{Glu} \rightarrow \mathrm{Ala}}$ (Bowman et al, 1964); D Ibadan is $\beta^{87 \mathrm{Thr} \rightarrow \text { Lys }}$ (Watson-Williams et al, 1965); D Bushman is $\beta^{16} \mathrm{Gly} \rightarrow \operatorname{Arg}$ (Wade, Jenkins, and Huehns, 1967).

Some confusion arose from the different behaviour on starch gel electrophoresis and paper electrophoresis at $\mathrm{pH} 8.6$ of some variants. $\mathrm{Hb} \mathrm{D}$ Punjab moves in the same manner as $\mathrm{Hb} S$ on both techniques. Certain haemoglobins, however, move slightly faster than $\mathrm{Hb} \mathrm{S}$ on paper electrophoresis 
particularly if barbitone buffer is used and these were named $\mathrm{Hb} \mathrm{G}$, but on starch gel electrophoresis they behave like $\mathrm{Hb} \mathrm{D}$. Depending on which medium research workers used for electrophoresis they named the haemoglobin variant $D$ or $G$.

This paper describes the occurrence of $\mathrm{Hb} \mathrm{D}$ Punjab in Canada and in the United Kingdom and reviews its global distribution.

\section{Hb D Punjab in Canada}

Between July 1965 and April 1973, some 222,000 blood samples obtained from blood donors or from hospital patients in various parts of the four Canadian provinces of Ontario, Manitoba, Saskatchewan, and Alberta were screened during a deliberate search for haemoglobin variants that have a different net charge from that of normal haemoglobin. For this purpose, a filter-paper electrophoresis technique was used (TEB-barbiturate discontinuous buffer system, pH 8.9; Vella, 1967). Twenty-nine of these specimens were found to contain an abnormal haemoglobin fraction which had the following properties: (1) it accounted for 30$40 \%$ of the total pigment, (2) it had the electrophoretic mobility of $\mathrm{Hb} \mathrm{S}$ at $\mathrm{pH} 8.9$, (3) it did not separate from $\mathrm{Hb} \mathrm{A}$ in citrate-agar gel electrophoresis at $\mathrm{pH} 6 \cdot 1$ (Robinson et al, 1957), (4) it was associated with a single haemoglobin $\mathrm{A}_{2}$ band of normal concentration, and with normal amounts of alkali-resistant haemoglobin $(0.5-1.5 \%$ by the one minute alkali denaturation method; Singer, Chernoff, and Singer, 1951), (5) it showed a normal solubility when reduced in $2.24 M$ phosphate buffer (Itano, 1953), and (6) it was not associated with sickling of erythrocytes when these were treated with metabisulphite. All these subjects were considered to be heterozygotes for an $\mathrm{Hb} \mathrm{D}$ gene. In 21 of them, the abnormal haemoglobin was isolated, purified, and characterized in Saskatoon on the basis of fingerprint patterns of tryptic digests by methods that have already been described (Vella et al, 1967b). Confirmatory results were obtained on three of these subjects by fingerprinting and by amino-acid analysis of isolated abnormal peptides undertaken at Cambridge. In all cases, the fingerprints were indistinguishable from those of $\mathrm{Hb} \mathrm{D}$ Punjab while the amino-acid analysis of aberrant peptides confirmed this characterization.

The incidence of $\mathrm{Hb} \mathrm{D}$ Punjab in the four provinces is summarized in Table $I$. Eight of these subjects were of East Indian origin, while the remainder were white Canadians of British stock. The overall frequency appears to be $1 / 10,000$ of the
TABLE I

HAEMOGLOBIN D PUNJAB IN CANADA*

\begin{tabular}{l|c|c|c}
\hline \multirow{2}{*}{ Province } & $\begin{array}{c}\text { No. of } \\
\text { Samples }\end{array}$ & \multicolumn{2}{|c}{ D Punjab } \\
\cline { 3 - 4 } & 14,700 & 3 & 1 \\
\hline Ontario & Total & $\begin{array}{c}\text { No. in } \\
\text { East } \\
\text { Indians }\end{array}$ \\
\hline Manitoba & 84,500 & 5 & 1 \\
\hline Saskatchewan & 81,400 & 9 & 3 \\
\hline Alberta & 26,700 & 4 & 3 \\
\hline Total & 207,300 & 21 & 8 \\
\hline
\end{tabular}

* No instance of this variant was encountered in 14,500 blood samples from persons of Canadian Indian origin.

population tested. If only the instances in white subjects are considered, the overall frequency becomes $1 / 16,000$ (ranging between $1 / 7,000$ in Ontario and 1/27,000 in Alberta).

\section{Hb D Punjab in the United Kingdom}

The first instances of $\mathrm{Hb} \mathrm{D}$ in English persons were reported by Stewart and MacIver (1956) from Jamaica, and Smith and Conley (1959) from North Carolina. The haemoglobin of the family reported by the latter was characterized as $\beta 121 \mathrm{Glu} \rightarrow \mathrm{Gln}$ by Baglioni (1962). Other instances of Hb D Punjabe in English persons abroad have been reported from Ghana (Ringelhann et al, 1967) and Australia? (Ungar et al, 1973).

Several extensive surveys have been undertaken in recent years to determine the incidence of abnormal haemoglobin variants in the United Kingdom. The frequency of $\mathrm{Hb} \mathrm{D}$ Punjab revealed by these is summarized in Table II. The first instance to be detected was that in an East Anglian family (Huntsman et al, 1963; Konigsberg et al, 1965). Black (1969) found four instances amongst some 8,000 newborn English infants that he tested. However, other surveys have given only negative results and the overall frequency in British persons appears to be about 1 in 7,500. This is in good agreement with the frequency suggested by the Canadian results. The incidence is much higher amongst recent immigrants to Britain, especially amongst those of Indian origin. A recent survey amongst some 7000 immigrant school children in Birmigham showed $\mathrm{Hb} \mathrm{D}$ to be present in $0.54 \%$ (Stuart et al, 1973).

During the last nine years, 27 instances of $\mathrm{Hb} \mathrm{D}$ Punjab have been characterized at the MRC Abnormal Haemoglobin Unit in Cambridge. The geographical origin of these is shown in Table III. 
TABLE II

INCIDENCE OF Hb D PUNJAB IN SURVEYS IN THE UNITED KINGDOM

\begin{tabular}{|c|c|c|c|}
\hline \multirow{2}{*}{ Source } & \multicolumn{2}{|c|}{ No. } & \multirow{2}{*}{ References } \\
\hline & Examined & $\underset{\text { Punjab }}{\mathrm{D}}$ & \\
\hline $\begin{array}{l}\text { British servicemen } \\
\text { in Singapore } \\
\text { and Malaysia }\end{array}$ & 4,387 & 0 & Vella $(1961 / 1962)$ \\
\hline Norfolk & 1,000 & 1 & $\begin{array}{l}\text { Huntsman et al (1963) } \\
\text { Konigsberg et al (1965) }\end{array}$ \\
\hline $\begin{array}{l}\text { Oxford and } \\
\text { Peterborough }\end{array}$ & 1,971 & 0 & Liddell et al (1964) \\
\hline Cambridge & 3,000 & 0 & Sick et al (1967) \\
\hline $\begin{array}{c}\text { London and other } \\
\text { English cities* }\end{array}$ & 10,000 & $6+$ & Black (1969) \\
\hline Londonf & 10,000 & 0 & $\begin{array}{l}\text { F. E. Boulton and R. G. } \\
\text { Huntsman (personal } \\
\text { communication) }\end{array}$ \\
\hline Scotland & 3,968 & 0 & Cook and Lehmann (1973) \\
\hline Ireland & 2,500 & 0 & $\begin{array}{l}\text { D. Tills (personal } \\
\text { communication) }\end{array}$ \\
\hline Total & 36,826 & 7 & \\
\hline
\end{tabular}

* Cord blood survey.

+ Includes two instances among East Indian immigrants.

$¥$ Myoglobin survey. (This survey did detect some instances of $\mathrm{Hb} \mathbf{S}$ and $\mathrm{C}$.)
TABLE III

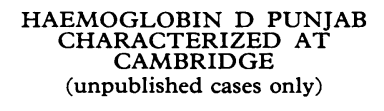

\begin{tabular}{l|c|c}
\hline \multirow{2}{*}{$\begin{array}{c}\text { Source of } \\
\text { Specimens }\end{array}$} & \multicolumn{2}{|c}{ D Punjab } \\
\cline { 2 - 3 } England & Total & $\begin{array}{c}\text { No. in } \\
\text { East } \\
\text { Indians }\end{array}$ \\
\hline Canada & 11 & 6 \\
\hline Australia & 5 & 2 \\
\hline South Africa & 2 & 1 \\
\hline Lebanon & 2 & - \\
\hline Italy & 1 & - \\
\hline Switzerland & $2 *$ & - \\
\hline France & 1 & - \\
\hline Portugal & 1 & - \\
\hline Venezuela & 1 & - \\
\hline
\end{tabular}

* Both Italians.

Eleven of them had come from England. However, only five had come from English persons (two from Leeds and three from London) while the remainder came from Indian immigrants.

\section{Global incidence and distribution}

The distribution and incidence of $\mathrm{Hb} \mathrm{D}$ Punjab is summarized in Table IV. While single instances of this variant have been reported in persons originating from various parts of Europe, the incidence increases appreciably from the Eastern Mediterranean to the western part of the Indian sub-continent, and especially in Iran, the Punjab, and the western half of India where between $1-2 \%$ may have the variant in their blood. It has been reported once from Thailand (Wasi et al, 1968) and has been found in a Batak Indonesian from Medan (L. E. Lie-Injo and J. Clegg, personal communication), but does not appear to have been encountered during extensive surveys in Taiwan (Blackwell and Liu, 1970; Blackwell et al, 1972) and Japan (Shibata, Iuchi, and Miyaji, 1966).

The spread of haemoglobin D Punjab to its present day geographical pattern may be explained on the basis of population migration occurring in two phases. The first phase would cover the period of the appearance of the mutation and its distribution to northern India, Iran, and Turkey and may reflect the pattern of migrations that occurred in that region during the times of Darius I of Persia or later during the Mogul invasions. The second would cover the spread of the gene to Western Europe and to the New World and may have resulted from intermarriage between Europeans and Indians over the last two or three centuries. Konigsberg et al (1965) have examined the evidence that this variant was introduced into Britain from the Punjab as a result of intermarriage of serving British troops with the Indian population during the 18th century. They concluded that the occasional examples of D Punjab found during surveys in Europeans (and especially in Britain, France, and Portugal) confirm the bonds that existed between these countries and India between the 17th and 20th centuries.

Though the earlier literature on haemoglobin variants contains many reports on the occurrence of $\mathrm{Hb} \mathrm{D}$ in negro subjects, especially in America (Chernoff, 1956; Chernoff and Weichselbaum, 1958; Marder and Conley, 1959; Myerson, Harrison, and Lohmuller, 1959; McCormick, 1960; Cawein et al, 1966) only in a very few cases has this been identified as D Punjab (Rothman and Ranney, 1971 ; P. R. McCurdy and H. Lehmann, unpublished results). In fact the commonest variant with the properties of $\mathrm{Hb} \mathrm{D}$ in American negroes is $\mathrm{Hb}$ G Philadelphia, and this appears to be widely distributed since it has also been found in the Congo (Dherte et al, 1959), in Nigeria (Lehmann and Nwokolo, 1959), and in the British West Indies 
TABLE IV

INCIDENCE AND DISTRIBUTION OF HAEMOGLOBIN D PUNJAB

\begin{tabular}{|c|c|c|c|c|}
\hline \multirow{2}{*}{ Country } & \multicolumn{2}{|c|}{ No. } & \multirow{2}{*}{ Reference } & \multirow{2}{*}{ Reference to Isolated Instances } \\
\hline & Examined & D Punjab & & \\
\hline United Kingdom & 36,826 & 7 & Table II & $\underset{\text { (1968) }}{\text { Ringelhann et al (1967); Schneider et al }}$ \\
\hline Portugal & 3042 & 0 & Trincao and Ferreira (1962) & \begin{tabular}{|l} 
Table III ; Preto et al (1961); Baglioni \\
(1962)
\end{tabular} \\
\hline France & - & - & - & $\begin{array}{l}\text { Table III; Labie and Rosa (1969); } \\
\text { Wajcman et al (1969) }\end{array}$ \\
\hline Holland & 991 & 1 & De Jong and Went (1968) & 一 \\
\hline Denmark & 5000 & 1 & Sick et al (1967) & - \\
\hline Norway & 3000 & 1 & Monn et al (1968) & - \\
\hline Sweden & 4171 & 0 & Nilsson and Eriksson (1972) & 一 \\
\hline Finland & 4418 & 0 & Nilsson and Eriksson (1972) & - \\
\hline Russia & 317 & 0 & Nilsson and Eriksson (1972) & - \\
\hline Germany & 一 & - & - & Martin et al (1960); Kohne et al (1972) \\
\hline Switzerland & 一 & - & - & Table III \\
\hline Italy & $\begin{array}{r}13,187 \\
3000\end{array}$ & $\begin{array}{l}0 \\
0\end{array}$ & $\begin{array}{l}\text { Quattrin et al (1966) } \\
\text { Licenziati (1969) }\end{array}$ & $\begin{array}{l}\text { Table III; Bowman and Ingram } \\
\text { (1961); Baglioni (1962); Ventruto } \\
\text { et al (1963); Cortesi et al (1966); } \\
\text { Ricco et al (1970); Rossi and } \\
\text { Morelli (1970) }\end{array}$ \\
\hline Bulgaria & 一 & - & 一 & Cholakov and Kanchev (1970) \\
\hline Yugoslavia & 2860 & 2 & Sadikario et al (1969) & 一 \\
\hline Greece & 1000 & 0 & Fessas (1959) & R. Rieder (personal communication) \\
\hline Turkey & - & - & - & Baglioni (1962); Ozsoylu (1970) \\
\hline Lebanon & 2938 & 0 & Cabannes et al (1965) & Table III \\
\hline Israel & $\begin{array}{l}397 \\
190\end{array}$ & $\begin{array}{l}0 \\
0\end{array}$ & $\begin{array}{l}\text { Dreyfus and Pinkhas (1958) } \\
\text { Beaven (1973) }\end{array}$ & Ramot et al (1969) \\
\hline Iran & $\begin{array}{l}400 \\
200 \\
184 \\
\end{array}$ & $\begin{array}{l}1 \\
2 \\
3 \\
\end{array}$ & $\begin{array}{l}\text { Rahbar et al (1967) } \\
\text { Rahbar et al (1967) } \\
\text { Lehmann et al (1973) }\end{array}$ & - \\
\hline Indian sub-continent & $\begin{array}{c}1000 \\
\text { (Bengal) } \\
129 \\
\text { (W. Pakistan) } \\
\end{array}$ & $\begin{array}{l}1 \\
1\end{array}$ & $\begin{array}{l}\text { Chatteriea (1959) } \\
\text { Stern et al (1968) }\end{array}$ & $\begin{array}{l}\text { Table I; Table II } \\
\text { Table III; Baglioni (1962); Marengo- } \\
\text { Rowe et al (1968) }\end{array}$ \\
\hline Thailand & 2790 & 0 & Flatz et al (1965) & Wasi et al (1968) \\
\hline Indonesia & 5400 & 0 & Lie-Injo (1959) & $\begin{array}{l}\text { L. E. Lie-Injo and J. Clegg (personal } \\
\text { communication) }\end{array}$ \\
\hline Taiwan & 100,000 & 0 & Blackwell and Liu (1970) & - \\
\hline Japan & 130,000 & 0 & Shibata et al (1966) & - \\
\hline Australia & - & - & - & Ungar et al (1973) \\
\hline South Africa & 3125 & 0 & Botha and van $\mathrm{Zyl}$ (1966) & Table III \\
\hline Canada & 207,300 & 21 & Table I & Table III \\
\hline Greenland & 153 & 0 & Nilsson and Eriksson (1972) & 一 \\
\hline Iceland & 1000 & 0 & Nilsson and Eriksson (1972) & - \\
\hline USA & - & - & - & $\begin{array}{l}\text { Stout et al (1964; see Arends, 1966); } \\
\text { Rothman and Ranney (1971); R. R. } \\
\text { McCurdy and H. Lehmann } \\
\text { (unpublished results); Imamura and } \\
\text { Riggs (1972) }\end{array}$ \\
\hline Jamaica & $\begin{array}{r}10,000 \\
3449 \\
\end{array}$ & $\begin{array}{l}\mathbf{0} \\
\mathbf{0}\end{array}$ & $\begin{array}{l}\text { Milner (1967) } \\
\text { Ahern et al (1973) }\end{array}$ & 二 \\
\hline Venezuela & 1666 & 0 & Arends (1963) & Table III; Arends (1971) \\
\hline Mexico & 2336 & 0 & Lisker et al (1966); Lisker (1971) & Schneider et al (1968); Bello et al (1969) \\
\hline
\end{tabular}


(Dance et al, 1964). Huisman (1969) has found 13 alpha-chain variants with the electrophoretic mobility of $\mathrm{Hb} \mathrm{D}$ or $\mathrm{G}$ but only three beta-chain variants with a similar mobility amongst 8500 negroes from Georgia (USA) examined. Also frequent in negroes originating in West Africa is $\mathrm{Hb}$ Korle-Bu ( $\beta 73$ Asp $\rightarrow$ Asn) which has been reported from Ghana (Konotey-Ahulu et al, 1968) as well as Martinique (Bookchin, Nagel, and Ranney, 1970). This variant is identical with Hb G Accra (Lehmann, Beale, and Boi-Doku, 1964; Boi-Doku, Kinderlerer, and Lehmann, 1972) and is the commonest form of $\mathrm{Hb} \mathrm{D}$ or $\mathrm{G}$ so far found in the British West Indies (Milner, 1967; Ahern, Swan, and Ahern, 1973). It has been suggested that the $\mathrm{Hb} \mathrm{D}$ found amongst negro subjects in South America (Venezuela-Arends, 1961; ColombiaRestrepo and Londoño, 1965; Brazil-de Araujo and Jamra, 1966) may have originated from the Iberian peninsula (de Araujo and Jamra, 1966). However, the $\mathrm{Hb} \mathrm{D}$ found in a Colombian negro family (Restrepo and Londoño, 1965) has been identified as $\mathrm{Hb}$ Korle-Bu (Restrepo, 1971). The $\mathrm{Hb} \mathrm{D}$ reported from some parts of Portuguese Africa (Trinc̃ao, 1967; David and Trinc̃ao, 1963) has not been characterized.

$\mathrm{Hb} \mathrm{D}$ Punjab has not been reported amongst Arab populations in North Africa. It has been suggested that the $\mathrm{Hb} \mathrm{D}$ that is present at appreciable frequency in the Arabo-Berbers of Algeria (Cabannes, 1965) may in fact be an alpha-chain variant (de Traverse and Coquelet, 1961; Konigsberg et al, 1965). More recently, however, two new variants of $\mathrm{Hb} \mathrm{D}$ have been reported in the Algerian population, one $\mathrm{Hb} \mathrm{D}$ Ouled Rabah $(\beta 19$ Asn $\rightarrow$ Lys $)$ and the other D Iran $(\beta 22 \mathrm{Glu} \rightarrow$ Gln) (Elion et al, 1973) the latter having also been reported in an Iranian (Rahbar, 1973) and in a Pakistani family (Rohe, Sharma, and Ranney, 1973).

A variant with the electrophoretic properties of $\mathrm{Hb} \mathrm{D}$ has been found amongst some groups of American Indians in the USA (Pollitzer et al, 1959; Githens et al, 1961) but not in South America (Colombia, Venezuela, British Guiana-Arends, 1963; de Pinango and Arends, 1965; Arends, 1971, Restrepo, 1971; Mexico-Lisker, Zarate, and Loria, 1966, Lisker, 1971; Brazil-Salzano and Tondo, 1968; de Araujo, 1971; San Salvador-Bloch and Rivera, 1969). Arends (1966) has summarized the results of haemoglobin studies of Indians of the American continent. The only variant with the properties of $\mathrm{Hb} \mathrm{D}$ that was found in Canadian Indians in Canada is Hb G Coushatta which was reported in a large family in Saskatchewan (Vella, Isaacs, and
Lehmann, 1967a; Vella and Guzak, 1968). It has since been found in 26 other Canadian Indians (12 each in Manitoba and Alberta and two in Ontario). This variant was originally discovered in the Alabama Coushatta Indians of Texas (Schneider et al, 1964; Bowman, Barnett, and Hite, 1967) and has more recently been reported in Korean and Chinese subjects (Blackwell et al, 1969).

\section{Addendum}

The following reported instances of Hb D Punjab were inadvertently omitted from Table IV: Greece (Deliyannis, Ballas, and Christakis, 1969) and Cuba (Uriarte, Perez Atencio, and Colombo, 1973).

$$
\text { REFERENCES }
$$

Deliyannis, G. A., Ballas, A., and Christakis, I. (1969). Haemoglabin D in a Greek family. Acta Haematologica, 41, 121-125.

Uriarte, A., Peres Atencio, R., and Colombo, B. (1973). Haemoglobin D Punjab in a Cuban family and its interaction with haemoglobin S. Acta Haematologica, 50, 315-320.

We are grateful to Drs F. E. Boulton, J. B. Clegg, R. G. Huntsman, L. E. Lie-Injo, R. Rieder, and D. Tills for permission to quote their unpublished data.

F. V. is grateful to A. Labossiere and Mrs M. Hurley for technical assistance and to the Medical Research Council of Canada for a grant.

\section{REFERENCES}

Ahern, E. J., Swan, A. V., and Ahern, V. N. (1973). The prevalence of the rarer inherited haemoglobin defects in adult Jamaicans. British fournal of Haematology, 25, 437-444.

Aksoy, M. and Lehmann, H. (1956). A further example of haemoglobin D in a Turkish family. Transactions of the Royal Society of Tropical Medicine and Hygiene, 50, 178-180.

Araujo, J. T. de (1971). Geographical distribution and incidence of hemoglobin variants in Brazil. In Genetical, Functional and Physical Studies of Hemoglobins, ed. by T. Arends, G. Bemski, and R. L. Nagel, pp. 26-31. Karger, Basel.

Araujo, J. T. de and Jamra, M. (1966). Incidence of abnormal hemoglobins in a sample of the Sao Paulo city population. Blood, 28, 495.

Arends, T. (1961). Frecuencia de las hemoglobinas anormales en Venezuela. Archivos del Hospital Vargas, 3, 225-236.

Arends, T. (1963). Search for abnormal hemoglobins in South American indians living in malarious zones. In Proceedings of the 7th International Congress on Tropical Medicine and Malaria, 4, 179-182. National Institute of Allergy and Infectious Diseases, Rio de Janeiro.

Arends, T. (1966). Haemoglobinopathies, thalassaemia and glucose-6-phosphate dehydrogenase deficiency in Latin America and the West Indies. New Zealand Medical fournal (Haematology suppl.), 65, 831-844.

Arends, T. (1971). Epidemiology of hemoglobin variants in Venezuela. In Genetical, Functional and Physical Studies of Hemoglobins, ed. by T. Arends, G. Bemski, and R. L. Nagel, pp. 82-98. Karger, Basel.

Arends, T., Layrisse, M., and Rincon, A. R. (1959). Sickle cellhaemoglobin D disease in a Portuguese child. Acta Haematologica, 22, 118-126.

Atwater, J., Schwartz, I. R., and Tocantins, L. M. (1960). A variety of human hemoglobin with four distinct electrophoretic components. Blood, 15, 901-908.

Babin, D. R., Jones, R. T., and Schroeder, W. A. (1964). Haemoglobin $\mathrm{D}_{\text {Los Angeles: }} \alpha_{2}^{\mathrm{A}} \beta_{2}{ }^{121} \mathrm{Glu} \mathrm{NH}_{2}$. Biochimica et Biophysica Acta, 86, 136-143.

Baglioni, C. (1962). Abnormal human haemoglobins. VII. Chemical studies on haemoglobin D. Biochimica Biophysica Acta, 59, 437-449. 
Baglioni, C. and Ingram, V. M. (1961). Abnormal human haemoglobins. V. Chemical investigation of haemoglobins A, G, C, X from one individual. Biochimica et Biophysica Acta, 48, 253-265.

Beaven, G. H. (1973). Haemoglobin studies of Yemenite and Kurdish Jews in Israel. Philosophical Transactions of the Royal Society of London, Series B, 266, 185-193.

Bello, A., Dorantes, S., and Alvarez, C. (1969). Hemoglobin D Punjab en una familia Mexicana, con dos casos clinicos de hemoglobinopatia S-D. Revista de Investigación Clinica, 21, 489-496.

Bird, G. W. G. and Lehmann, H. (1956). Haemoglobin D in India. British Medical fournal, 1, 514.

Black, A. J. (1969). A Survey of Umbilical Cord Blood for Haemoglobin Variants. MD Thesis, Cambridge University.

Blackwell, R. Q. and Liu, C. S. (1970). Hemoglobin G Taichung: $\alpha^{74}$ Asp $\rightarrow$ His. Biochimica et Biophysica Acta, 200, 70-75.

Blackwell, R. Q., Ro, I. H., Liu, C. S., Yang, H. J., Wang, C. C., and Huang, J. T. S. (1969). Hemoglobin variant found in Koreans, Chinese, and North American Indians: $\alpha_{2} \beta_{2}(22 \mathrm{Glu} \rightarrow$ Ala). American fournal of Physical Anthropology, 30, 389-391.

Blackwell, R. Q., Weng, M. I., Liu, C. S., Shih, T. B., and Wang, C. L. (1972). Hemoglobin G Chinese in Chinese subjects in Taiwan. Vox Sanguinis, 23, 363-368.

Bloch, M. and Rivera, H. (1969). Hemoglobinas anormales y deficiencia de glucosa-6-fosfato-dehidrogenasa en El Salvador. Sangre, 14, 121-124.

Boi-Doku, F. S., Kinderlerer, J., and Lehmann, H. (1972). In Atlas of Protein Sequence and Structure, ed. by M. Dayhoff, p. 73. National Biomedical Research Foundation, Silver Springs.

Bookchin, R. M., Nagel, R. L., and Ranney, H. M. (1970). The effects of $\beta 73$ Asn on the interactions of sickling hemoglobin. Biochimica et Biophysica Acta, 221, 373-375.

Botha, M. C. and Zyl, L. J. van (1966). Abnormal haemoglobins in Cape Town. Occurrence and significance. South African Medical Fournal, 40, 753-756.

Bowman, B. H., Barnett, D. R., and Hite, R. (1967). Hemoglobin G-Coushatta: a beta variant with a delta-like substitution. Biochemical and Biophysical Research Communications, 26, 466-470.

Bowman, B. H., Barnett, D. R., Hodgkinson, K. T., and Schneider, R. G. (1966). Chemical characterization of haemoglobin $\mathrm{G}_{\mathrm{St}-1}$. Nature, 211, 1305-1306.

Bowman, B. H. and Ingram, V. M. (1961). Abnormal human haemoglobins. VII. The comparison of normal human haemoglobins with haemoglobin D Chicago. Biochimica et Biophysica Acta, 53, 569-573.

Bowman, B. H., Oliver, C. P., Barnett, D. R., Cunningham, J. E., and Schneider, R. G. (1964). Chemical characterization of three hemoglobins G. Blood, 23, 193-199.

Cabannes, R. (1965). Répartition des hémoglobines anormales dans la partie ouest du continent Africain. In Abnormal Haemoglobins in Africa, ed. by J. H. P. Jonxis, pp. 291-317. Blackwell Scientific, Oxford.

Cabannes, R., Taleb, N., Ghorra, F., and Schmitt-Beurrier, A. (1965). Études des types hémoglobiniques dans la population du Liban. Nouvelle Revue Francaise d'Hématologie, 5, 851-856.

Cawein, M. J., Lappatt, E. J., Brangle, R. W., and Farley, C. H. (1966). Hemoglobin S-D disease. Annals of Internal Medicine, 64, 62-70.

Chatterjea, J. B. (1959). Haemoglobinopathy in India. In Abnormal Haemoglobins, ed. by J. H. P. Jonxis and J. F. Delafresnaye, pp. 322-329. Blackwell Scientific, Oxford.

Chernoff, A. I. (1956). On the prevalence of hemoglobin D in the American negro. Blood, 11, 907-909.

Chernoff, A. I. (1958). The hemoglobin D syndromes. Blood, 13, 116-127.

Chernoff, A. I. and Pettit, N. (1965). The amino acid composition of hemoglobin. VI. Separation of the tryptic peptides of hemoglobin Knoxville No. 1 on Dowex-1 X-2 and Sephadex. Biochimica et Biophysica Acta, 97, 47-60.

Chernoff, A. I. and Weichselbaum, T. E. (1958). A microhemolyzing technic for preparing solutions of hemoglobin for paper electrophoretic analysis. American fournal of Clinical Pathology, 30, 120-125.

Cholakov, B. and Kanchev, K. N. (1970). A case of hemoglobinosis (In Bulgarian). Savremmena Medicina, 21, 24-26.

Cook, I. A. and Lehmann, H. (1973). Beta-thalassaemia and some rare haemoglobin variants in the highlands of Scotland. Scottish Medical fournal, 18, 14-20.
Cortesi, S., Vettore, L., Carta, S., Sorcini, M., and De Sandre, G. (1966). Associazone di emoglobinosi D Los Angeles $\alpha \beta$-talassemia in una famiglia Veneta. Acta Medica Patavina, 26, 262291.

Dacie, J. V. (1954). The Haemolytic Anaemias: Congenital and Acquired, p. 146. Grune and Stratton, New York.

Dance, N., Huehns, E. R., and Shooter, E. M. (1964). The chemical investigation of haemoglobins $\mathrm{G}$ Bristol and $\mathrm{G}$ Bristol/C. Biochimica et Biophysica Acta, 86, 144-148.

David, J. H. Santos and Trinc̃ao, C. (1963). Drepanocitemia, deficiéncia da desidrogenase da glucose-6-fosfata (G-6-PD) eritrocitária e paludismo no posto do Cuango (Lunda-Angola). Anais do Instituto de Medicina Tropical, 20, 5-16.

Dherte, P., Vandepitte, J., Ager, J. A. M., and Lehmann, H. (1959). Stanleyville I and II. Two new variants of adult haemoglobin. British Medical fournal, 2, 282-284.

Dreyfus, F. and Pinkhas, J. (1958). Search for abnormal haemoglobins in oriental Jews. Lancet, 2,1180

Elion, J., Belkhodja, O., Wajcman, H., and Labie, D. (1973). Two variants of hemoglobin $\mathrm{D}$ in the Algerian population: Hemoglobin $D$ Ouled Rabah $\beta 19$ (B1) Asn $\rightarrow$ Lys and hemoglobin D Iran B22 (B4) Glu $\rightarrow$ Gln. Biochimica et Biophysica Acta, 310, 360-364.

Fessas, P. (1959). The hereditary anaemias in Greece. In Abnormal Haemoglobins, ed. by J. H. P. Jonxis and J. F. Delafresnaye, pp. 260-270. Blackwell Scientific, Oxford.

Flatz, G., Pik, C., and Sringam, S. (1965). Haemoglobinopathies in Thailand. II. Incidence and distribution of elevations of haemoglobin $\mathrm{A}_{2}$ and haemoglobin F. A survey of 2790 people. British fournal of Haematology, 11, 227-236.

Gammack, D. B., Huehns, E. R., Lehmann, H., and Shooter, E. M. (1961). The abnormal polypeptide chains in a number of haemoglobin variants. Acta Genetica et Statistica Medica, 11, 1-16.

Githens, J. H., Knock, H. K., and Hathaway, W. E. (1961). Prevalance of abnormal hemoglobins in American Indian children. Survey in the Rocky Mountain area. Fournal of Laboratory and Clinical Medicine, 57, 755-758.

Gouttas, A., Tsevrenis, H., Papaspyrou, A., Pougouras, P., Fertakis, A., and Vorias, N. (1960). L'hemoglobinose D en Grèce. Sang, 31, 303-306.

Huisman, T. H. J. (1969). Human hemoglobins. In Biochemicato Methods in Red Cell Genetics, ed. by J. J. Yunis, pp. 391-504 Academic Press, New York.

Huntsman, R. G., Hall, M., Lehmann, H., and Sukumaran, P. K. (1963). A second and a third abnormal haemoglobin in Norfolk. Haemoglobin $\mathrm{G}_{\text {Norfolk }}$ and Haemoglobin $\mathrm{D}_{\text {Norfolk. British }}$ Medical fournal, 1, 720-722.

Hynes, M. and Lehmann, H. (1956). Haemoglobin D in a Persian girl; presumably the first case of haemoglobin-D-thalassaemia. British Medical fournal, 2, 923-924.

Imamura, T. and Riggs, A. (1972). Identification of hemoglobin Oak Ridge with hemoglobin D Punjab (Los Angeles). Biochemical Genetics, 7, 127-130.

Itano, H. A. (1951). Third abnormal hemoglobin associated with hereditary hemolytic anemia. Proceeedings of the National Academy of Sciences, 37, 775-784.

Itano, H. A. (1953). Solubilities of naturally occurring mixtures of human hemoglobin. Archives of Biochemistry and Biophysics, 47, 148-159.

Jacob, G. F., Lehmann, H., and Raper, A. B. (1956). Haemoglobin D in Indians of Gujerati origin in Uganda. East African Medical fournal, 33, 135-138.

Jong, W. W. W. de and Went, L. N. (1968). Haemoglobin J Baltimore $\left(\alpha_{2} \beta_{2} 16\right.$ Gly $\left.\rightarrow A s p\right)$ and haemoglobin D Punjab $\left(\alpha_{2} \beta_{2}{ }^{121}\right.$ Glu $\rightarrow \mathrm{Gln}$ ) in two Dutch families. Acta Genetica et Statistica Medica, 18, 429-443.

Kohne, E., König, E., and Roggenbach, H. J. (1972). Hämoglobin D-Punjab bei einem deutschen Patienten. Verhandlungen der Deutschen Gesellschaft für Innere Medizin, 78, 1596-1597.

Konigsberg, W., Huntsman, R. G., Wadia, F., and Lehmann, H. (1965). Haemoglobin $\mathrm{D} \beta_{\text {Punfab }}$ in an East Anglian family. fournal of the Royal Anthropological Institute, 95, 295-306.

Konotey-Ahulu, F. I. D., Gallo, E., Lehmann, H., and Ringelhann B. (1968). Haemoglobin Korle-Bu ( $\beta 73$ aspartic acid $\rightarrow$ asparagine). Fournal of Medical Genetics, 5, 107-111.

Labie, D. and Rosa, J. (1969). Structure de quelques hémoglobines anormales. Annales de la Société Belge de Médécine Tropicale 49 99-107. 
Lehmann, H., Ala, F., Hedeyat, S., Montazemi, K., Nejad, H. K., Lightman, S., Kopec, A. C., Mourant, A. E., Teesdale, P., and Tills, D. (1973). The hereditary blood factors of the Kurds of Iran. Philosophical Transactions of the Royal Society of London, Series B, 226, 195-205.

Lehmann, H., Beale, D., and Boi-Doku, F. S. (1964). Haemoglobin $G_{\text {Accra. }}$ Nature, 203, 363-365.

Lehmann, H. and Nwokolo, C. (1959). The river Niger as a barrier in the spread eastwards of haemoglobin C: a survey of haemoglobins in the Ibo. Nature, 183, 1587-1588.

Licenziati, M. (1969). Incidenza delle emoglobinopatie nella Provincia di Napoli. Minerva Medica, 60, 140-141.

Liddell, J., Brown, D., Beale, D., Lehmann, H., and Huntsman, R. G. (1964). A new haemoglobin-J $\alpha$ Oxford found during a survey of an English population. Nature, 204, 269-270.

Lie-Injo, L. E. (1959). Pathological haemoglobins in Indonesia. In Abnormal Haemoglobins, ed. by J. H. P. Jonxis and J. F. Delafresnaye, pp. 368-383. Blackwell Scientific, Oxford.

Lisker, R. (1971). Distribution of abnormal hemoglobins in Mexico. In Genetical, Functional and Physical Studies of Hemoglobins, ed. by T. Arends, G. Bemski, and R. L. Nagel, pp. 8-14. Karger, Basel.

Lisker, R., Zarate, G., and Loria, A. (1966). Studies on several genetic hematologic traits of Mexicans. IX. Abnormal hemoglobins and erythrocytic glucose-6-phosphate dehydrogenase deficiency in several Indian tribes. Blood, 27, 824-830.

McCormick, W. F. (1960). Abnormal hemoglobins. I. Incidence in Memphis and Western Tennessee, with special reference to autopsy material. American fournal of Clinical Pathology, 34, 220-224.

McCurdy, P. R. (1959). Clinical and physiologic studies in a negro with sickle cell hemoglobin D disease. New England fournal of Medicine, 262, 961-964.

McCurdy, P. R., Pearson, H., and Gerald, P. S. (1961). A new hemoglobinopathy of unusual genetic significance. fournal of Laboratory and Clinical Medicine, 58, 86-94.

Marder, V. J. and Conley, C. L. (1959). Electrophoresis of hemoglobin on agar gels: frequency of hemoglobin D in a negro population. Bulletin of the fohns Hopkins Hospital, 105, 77-88.

Marengo-Rowe, A. J., McCracken, A. W., and Flanagan, P. (1968). Complete suppression of haemoglobin A synthesis in haemoglobin D Los Angeles-beta thalassaemia. Fournal of Clinical Pathology, 21, 508-510.

Martin, H., Heupke, G., Pfleiderer, G., and Wörner, W. (1960). Hämoglobin D in einer Frankfurter Familie. Folia Haematologica, 4, 233-241.

Milner, P. F. (1967). High incidence of haemoglobin G Accra in a rural district of Jamaica. Fournal of Medical Genetics, 4, 88-90.

Minnich, V., Cordonnier, J. K., Williams, W. J., and Moore, C. V. (1962). Alpha, beta, and gamma hemoglobin polypeptide chains during the neonatal period with description of a fetal form of $\mathrm{D} \alpha$ st Louis. Blood, 19, 137-167.

Monn, E., Gaffney, P. J., and Lehmann, H. (1968). Haemoglobin Sogn ( 114 arginine). A new haemoglobin variant. Scandinavian fournal of Haematology, 5, 353-360.

Myerson, R. M., Harrison, E., and Lohmuller, A. W. (1959). Incidence and significance of abnormal hemoglobins. American fournal of Medicine, 26, 543-546.

Nilsson, L. O. and Eriksson, A. W. (1972). Screening for haemoglobin and lactate dehydrogenase variants in the Icelandic, Swedish, Finnish, Lappish, Mari, and Greenland Eskimo populations. Human Heredity, 22, 372-379.

Ózsoylu, S. (1970). Homozygous hemoglobin D Punjab. Acta Haematologica, 43, 353-359.

Pinango, C. L. A. de and Arends, T. (1965). Hemoglobinas anormales en donantes de sangre nativos del Estado Bolívar. Acta Cientifica Venezolana, 16, 215-218.

Pollitzer, W. S., Chernoff, A. I., Horton, L. L., and Froehlich, M. (1959). Hemoglobin patterns in American Indians. Science, $129,216$.

Preto, R. V., Trincao, C., Melo, J., Cordeiro Ferreria, N., and Coutinho, P. (1961). Consideracoes sobre numa hemoglobinopatia familiar associacao talassemia-hemoglobina D numa familia algarvia. Boletim Clinico dos Hospitais Civis de Lisboa, 25, 483-486.

Quattrin, N., Bianchi, P., Cimino, P., De Rosa, L., Dini, E., Montuori, R., and Ventruto, V. (1966). Le microcitemie ed altre emoglobinopatie in Campania. Cinque anni de recherche. Riforma Medica, 80, 285-295.
Rahbar, S. (1973). Haemoglobin D Iran: $\beta_{2} 22$ Glutamic acld $\rightarrow$ Glutamine (B4). British fournal of Haematology, 24, 31-35.

Rahbar, S., Beale, D., Isaacs, W. A., and Lehmann, H. (1967). Abnormal haemoglobins in Iran. Observation of a new varianthaemoglobin J Iran $\left(\alpha_{2} \beta_{2}{ }^{77} \mathrm{His} \rightarrow\right.$ Asp $)$, British Medical fournal, 1 , 674-677.

Ramot, B., Rotem, J., Rahbar, S., Jacobs, A. S., Udem, L., and Ranney, H. M. (1969). Hemoglobin D Punjab in a Bulgarian Jewish family. Israel fournal of Medical Sciences, 5, 1066-1070.

Raper, A. B., Gammack, D. B., Huehns, E. R., and Shooter, E. M. (1960). Four haemoglobins in one individual. A study of the genetic interaction of $\mathrm{Hb}-\mathrm{G}$ and $\mathrm{Hb}-\mathrm{C}$. British Medical fournal, 2, 1257-1261.

Restrepo, A. (1971). Frequency and distribution of abnormal hemoglobins and thalassemia in Colombia, South America. In Genetical, Functional and Physical Studies of Hemoglobins, ed. by T. Arends, G. Bemski, and R. L. Nagel, pp. 39-52. Karger, Basel.

Restrepo, H. A. and Londoño, O. G. (1965). Sickle cell hemoglobin D disease in a negro Colombian patient. Annals of Internal Medicine, 62, 1301-1306.

Ricco, G., Gallo, E., Mazza, U., Papa, G., and Inglott, G. (1970). Su un caso di emoglobina D Punjab $\left(\alpha_{2} \beta_{2}{ }^{121} \mathrm{Glu} \rightarrow \mathrm{G} \ln \right)$. Bolletino della Società Italiana di Biologia Sperimentale, 46, 341-344.

Ringelhann, B., Lewis, R. A., Lorkin, P. A., Kynoch, P. A. M., and Lehmann, H. (1967). Sickle-cell haemoglobin D Punjab disease: $\mathrm{S}$ from Ghana and D from England. Acta Haematologica, 38 , 324-331.

Robinson, A. R., Robson, M., Harrison, A. P., and Zuelzer, W. W. (1957). A new technique for the differentiation of hemoglobin. fournal of Laboratory and Clinical Medicine, 50, 745-752.

Rohe, R. A., Sharma, V., and Ranney, H. M. (1973). Hemoglobin D Iran $\alpha_{2} \mathrm{~A}_{2}{ }^{22 \mathrm{Glu}} \rightarrow \mathrm{Gln}$ in association with thalassemia. Blood, 42, 455-462.

Rossi, U. and Morelli, A. (1970). Emoglobine rare: frequenza presso la popolazione della provincia di Milano. Folia Hereditaria et Pathologica, 19, 29-33.

Rothman, M. C. and Ranney, H. M. (1971). Double heterozygosity for hemoglobin $G\left(\alpha^{68 \text { Lys }_{B_{2}} \mathrm{~A}}\right)$ and hemoglobin $D$ $\left(\alpha_{2}{ }^{\mathrm{A}} \beta_{2}{ }^{121} \mathrm{Gln}\right)$. Blood, 37, 177-183.

Sadikario, A., Duma, H., Efremov, G., Mladenovski, B., Andreeva, M., Petkov, G., and Lazova, C. (1969). Thalassaemias and abnormal haemoglobins in SR Macedonia. Acta Haematologica, 41, 162-169.

Salzano, P. M. and Tondo, C. V. (1968). Hemoglobin types of Brazilian Indians. American fournal of Physical Anthropology, 28, 355-359.

Schneider, R. G., Haggard, M. E., McNutt, C. W., Johnson, J. E., Bowman, B. H., and Barnett, D. R. (1964). Hemoglobin $\mathrm{G}_{\text {Coushatta }}$ a new variant in an American Indian family. Science, 143, 697-698.

Schneider, R. G., Ueda, S., Alperin, J. B., Levin, W. C., Jones, R. T., and Brimhall, B. (1968). Hemoglobin D Los Angeles in two Caucasian families: hemoglobin SD disease and hemoglobin D thalassemia. Blood, 32, 250-259.

Shibata, S., Iuchi, I., and Miyaji, T. (1966). Abnormal hemoglobins discovered in Japan. Bulletin of the Yamaguchi Medical School, 13, 1-17.

Sick, K., Beale, D., Irvine, D., Lehmann, H., Goodall, P. T., and MacDougall, S. (1967). Haemoglobin $G_{\text {Copenhagen and haemo- }}$ globin J Cambridge. Two new $\beta$-chain variants of haemoglobin $A$. Biochimica Biophysica Acta, 140, 231-242.

Singer, K., Chernoff, A. I., and Singer, L. (1951). Studies on abnormal hemoglobins. I. Their demonstration in sickle cell anemia and other hematologic disorders by means of alkali denaturation. Blood, 6, 413-429.

Smith, E. W. and Conley, C. L. (1959). Sickle cell-hemoglobin D disease. Annals of Internal Medicine, 50, 94-105.

Stern, M. A., Kynoch, P. A. M., and Lehmann, H. (1968). $\beta-$ Thalassaemia, glucose-6-phosphate dehydrogenase deficiency and haemoglobin D-Punjab in Pathans. Lancet, 1, 1284-1285.

Stewart, J. N. and MacIver, J. G. (1956). Sickle cell-haemoglobin-D disease in a mulatto girl. Lancet, 1, 23-25.

Stout, C., Holland, C. K., and Bird, R. M. (1964). Hemoglobin D in an Oklahoma family. Archives of Internal Medicine, 114, 296300 . 
Stuart, J. C., Schwartz, F. C. M., Little, A. J., and Raine, D. N. (1973). Screening for abnormal haemoglobins: a pilot study. British Medical fournal, 4, 284-287.

Sturgeon, P., Itano, H. A., and Bergren, W. R. (1955). Clinical manifestations of inherited abnormal hemoglobins. I. The interaction of hemoglobin-S with hemoglobin-D. Blood, 10, 389-404.

Traverse, P. M. de and Coquelet, M. L. (1961). Hémoglobine foetale anormale chez un enfant hétérozygote AD. Hypothese structurale. Comptes Rendus des Séances de la Societé de Biologie et de ses Filiales, 155, 1888-1892.

Trinc̃ao, C. (1967). Hemoglobinas anormais nos territorios Portuguesas. Boletim Clinico dos Hospitais Civis Lisboa, 21, 813-827.

Trinc̃ao, C. and Ferreira, C. N. (1962). Thalassaemia in Portugal. In Proceedings of the 8th Congress of the European Society of Haematology, pt. 2, 307a. Karger, New York.

Ungar, B., Symons, H. S., Anderson, G. R., Stubbs, A. E., Wiltshire, B. G., and Lehmann, H. (1973). Haemoglobin D Punjab in a European family in Australia. Medical fournal of Australia, 1, 354-356.

Vella, F. (1961/1962). Abnormal haemoglobins, thalassaemia and erythrocyte glucose-6-phosphate dehydrogenase deficiency in Singapore and Malaya. Oceania, 32, 219-225.

Vella, F. (1967). Haemoglobin variants in Saskatchewan. Clinical Biochemistry, 1, 118-134.

Vella, F. and Guzak, P. (1968). Haemoglobin variants and thalassaemia in Saskatchewan Indians. Clinical Biochemistry, 2, 153157.

Vella, F., Isaacs, W. A., and Lehmann, H. (1967a). Hemoglobin G

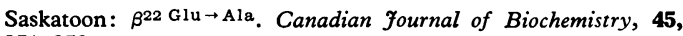
351-353.

Vella, F., Lorkin, P. A., Carrell, R. W., and Lehmann, H. (1967b) $A$ new hemoglobin variant resembling hemoglobin $E$. Hemoglobin E Saskatoon: $\beta^{22} \mathrm{Glu} \rightarrow \mathrm{Lys}$. Canadian fournal of Biochemistry, 45, 1385-1391.

Ventruto, V., Colombo, B., Caniglia, A., and De Rosa, L. (1963). Studio di tre famiglie con emoglobinosi D. Haematologica, 48, 873-884.

Wade, P. T., Jenkins, T., and Huehns, E. R. (1967). Haemoglobin variant in a Bushman: Haemoglobin $D \beta$-Bushman $\alpha \beta_{22}{ }^{16}$ Gly $\rightarrow$ Arg . Nature, 216, 688-690.

Waicman, H., Boigne, J. M., Labie, D., and Seringe, P. (1969). Hémoglobine $\mathrm{D}$ Los Angeles. Mise en évidence de l'anomalie de structure par une amélioration des méthodes. Biochimica et Biophysica Acta, 188, 55-58.

Wasi, P., Pootrakul, S., Na-Nakorn, S., Beale, D., and Lehmann, H. (1968). Haemoglobin D Los Angeles (D Punjab, $\alpha_{2} \beta_{2}{ }^{121} \mathrm{Glu}$. NH $\mathrm{H}_{2}$ ) in a Thai family. Acta Haematologica, 39, 151-158.

Watson-Williams, E. J., Beale, D., Irvine, D., and Lehmann, $H$. (1965). A new haemoglobin D Ibadan ( $\beta-87$ threonine $\rightarrow$ lysine $)$ producing no sickle-cell haemoglobin $\mathrm{D}$ disease with haemoglobin S. Nature, 205, 1273-1276.

Weatherall, D. J., Sigler, A. T., and Baglioni, C. (1962). Four hemoglobins in each of three brothers. Genetic and biochemical significance. Bulletin of the fohns Hopkins Hospital, 111, 143-156.

White, J. C. and Beaven, G. H. (1954). A review of the varieties of human haemoglobin in health and disease. Fournal of Clinical Pathology, 7, 175-200.

\section{Oxford Symposium}

A symposium on 'The 'eye in the inborn errors of metabolism' will take place at Oxford University, Oxford, England from 13 to 16 April 1975. Speakers will include: Norman Ashton, Elmer Ballintine, Elaine Berman, Anthony Bron, Donald Bergsma, Elliot Berson, Robert P. Burns, Ronald E. Carr, David G. Cogan, Patrick I. Condon, Edward Cotlier, Harold Cross, Glyn Dawson, Monte A. Del Monte, Albert T. Franceschetti, Jules Francois, Alec Garner, Morton Goldberg, Brian Harcourt, William F. Hughes, Barrie Jay, Kenneth Kenyon, Gordon Klintworth, Toichiro Kuwabara, Irene Hussels-Maumenee, Michael D. Sanders, Jack D. Singer, George Spaeth, C. Takki, Ramesh Tripathi, Ruth van Heyningen, J. M. Walshe, Warren Wilson, Jonathan Wirschafter, Vernon Wong, Wolfgang Zeman. A limited number of free papers will be accepted. Ophthalmologists, paediatricians, or basic scientists are invited to attend; register in advance. For information regarding registration or participation, contact the symposium organizers; Edward Cotlier, MD, University of Illinois Eye and Ear Infirmary, 1855 W. Taylor Street, Chicago, Illinois 60612, USA, or Anthony Bron, FRCS, University of Oxford Nuffield Laboratory of Ophthalmology, Walton Street, Oxford OX2 6AN, England. 